\title{
Straparola and the Fairy Tale: Between Literary and Oral Traditions
}

\section{Citation}

Jan M. Ziolkowski. 2010. "Straparola and the Fairy Tale: Between Literary and Oral Traditions." Journal of American Folklore 123 (490): 377-397. doi:10.1353/jaf.2010.0002.

\section{Published Version}

doi:10.1353/jaf.2010.0002

\section{Permanent link}

http://nrs.harvard.edu/urn-3:HUL.InstRepos:14326347

\section{Terms of Use}

This article was downloaded from Harvard University's DASH repository, and is made available under the terms and conditions applicable to Other Posted Material, as set forth at http:// nrs.harvard.edu/urn-3:HUL.InstRepos:dash.current.terms-of-use\#LAA

\section{Share Your Story}

The Harvard community has made this article openly available.

Please share how this access benefits you. Submit a story.

Accessibility 
JAN M. ZiOLKOWSKI

\title{
Straparola and the Fairy Tale: Between Literary and Oral Traditions
}

\begin{abstract}
Against Ruth B. Bottigheimer's argument that the sixteenth-century Italian author Giovanni Francesco Straparola originated fairy tale in its best-known form, this article maintains that ancient and medieval texts contain earlier literary adaptations of folktales that qualify as fairy tales. Particular attention is paid to similarities between Straparola's "Il re porco" and the Medieval Latin Asinarius. Such affinities suggest that oral tradition is not as difficult to document before the print era as Bottigheimer asserts. With regard to her theory that Straparola invented the narrative pattern that she calls "rise tales," this article offers evidence that one such tale may be found as early as the second century CE, in Apuleius's famous "Cupid and Psyche." In the nineteenth and twentieth centuries folklorists were deeply concerned with studying the distribution of folktales across space and time; their key preoccupations were questions about origins and about the relationship between orality and literacy. These issues deserve to retain a central place in folklore studies.
\end{abstract}

FAIRY GODFATHER: STRAPAROLA, VENICE, AND THE FAIRY TALE TRADITION (2002), a tract of around 150 pages, delivers a major thrust in a war that its author, Ruth B. Bottigheimer, has been waging at least since 1994. The book will not become a landmark in folkloristics in general, and only time will tell if it has a lasting impact even within fairy-tale studies. Yet although the book is sui generis, the views that it advocates and the controversies it arouses relate to important issues in folklore studies, beyond what the specificity of its title might suggest. Indeed, Bottigheimer's book opens up grand questions about the definition of fairy tale as a genre, about the status of the centuries-old search for the origins of fairy tales, about the relationships between orality and literacy, and about the relevance of recent directions in performance studies to folktale and fairy-tale studies. A still larger issue that this sort of book might induce folklorists to ponder is what place the study of folktales should occupy within folkloristics as a whole: folktales were foundational in the history of folklore studies in the nineteenth century and later, but as a lingering romantic nostalgia for folk culture has given way to a postmodern gusto for mass culture, it may be only natural that the tales have come to play a diminished role today.

JAN M. Ziolkowski is Arthur Kingsley Porter Professor of Medieval Latin at Harvard University and Director of the Dumbarton Oaks Research Library and Collection in Washington, D.C.

Journal of American Folklore 123(490):377-397

Copyright (C) 2010 by the Board of Trustees of the University of Illinois 
On the destructive side, Bottigheimer campaigns against what she regards as inherent flaws in the methods of folk narrative research. Constructively, she advocates that in defining and studying what is conventionally called fairy tale, we focus upon extant print evidence and shun speculation about supposedly lost oral versions (Bottigheimer 2002, 2003). Bottigheimer's study of the sixteenth-century Italian author Giovanni Francesco Straparola renews, in a style very much her own, a clash that took place in the first half of the twentieth century when Albert Wesselski advanced provocations against the European folkloristics establishment (Wesselski 1931; see discussion in Kiefer 1947). Wesselski's stance itself bore a resemblance to that of André Jolles, whose Einfache Formen (Simple forms) (1930) had a great impact on genre theory in literary studies as well as in folkloristics (see Cocchiara 1981:514). In particular, Bottigheimer effectively revitalizes-at least in the case of Straparola-Wesselski's assertion that authorship cannot be attributed to the "folk" as a whole but only to individual storytellers and especially storywriters. In the process, she also renews, with minor changes, a long-superseded clash over the relative worth of folktale records preserved through orality and those preserved in literature, which in the past pitted one extreme of folkloristics against another of philology (Rosenberg 1991; on the related conflict between literary and anthropological folklorists in the United States, see Zumwalt 1988).

In her 2002 book, Bottigheimer advances the stout claim that Straparola created in Le piacevoli notti (Pleasant nights) what she regards as the classic fairy tale, the plot that traces the rags-to-riches ascent of a poor hero or heroine who has magical assistance in marrying into royalty and obtaining wealth (for an Italian edition of Le piacevoli notti, see Straparola [1551-3] 2000; for an English translation see Straparola [1551-3] 1898). According to Bottigheimer, the tales that Straparola invented established the genre of the modern fairy tale in its most familiar guise: "Straparola's rise tales marked the beginning of all modern fairy tales that reassured their readers that even the most miserably poor boy or girl could gain enormous material wealth" (2002:6). As his stories achieved commercial success through repeated printings, they became diffused throughout the world. Without becoming mired in questions of the chicken and the egg, it is nonetheless fair to say that Bottigheimer sees Straparola as having been the goose that laid the archetypal golden eggs of fairy tale.

The argument that a single sixteenth-century author originated fairy tale as it is most commonly conceived exceeds in its specificity (and in its radicality) the results of previous searches for the origins of fairy tale as a genre. Such searching came to one early culmination in the so-called historic-geographic or Finnish method of folktale study, which arose ultimately out of quests for origins that were created and refined with application to texts, and especially to literary texts, in the various national philologies (Bendix 1997:66-7). The historic-geographic method has led to accumulations of information about thousands of folktales, including many fairy tales, and to studies that point to the broad diffusion of tales across both space and time. The directions marked out by these studies contrast with Bottigheimer's focus on more recent, and more specific, literary origins. Bottigheimer's reasoning that fairy tale was created in the sixteenth century and no earlier also runs counter to independent efforts that have been made in the opening decade of the twenty-first century to broaden the scope of 
inquiry into the lineage of folktales and fairy tales to encompass ancient and medieval evidence (Anderson 2000; Hansen 2002; Ziolkowski 2007).

Bottigheimer advances a thesis that Straparola composed what she calls "restoration fairy tales" by adapting existing plots from medieval and contemporary romances (2002:11-3). Restoration tales begin with a protagonist who initially loses high status but who later is restored to it. The sort of adaptation that Bottigheimer hypothesizes is possible, but it must be observed immediately that many of the literary romances are argued to have drawn from sources in oral folklore. One indicator of the close proximities that have been perceived between medieval romances and oral tradition is the existence of motif-indices for romances (Bordman 1963; Birkhan, Lichtblau, and Tuczay 2005-6). Thus, the contention that Straparola devised his restoration fairy tales by abridging the narratives of literary romances and capping them with happy endings could be misleading. In the absence of evidence that proves his indebtedness to a particular text, it remains equally plausible that the Italian author was inspired by oral forms. Whether those oral forms were themselves obliged directly or indirectly to texts puts us once again in the zone of questions about the chicken or the egg that have vexed for so long and to so little avail investigations of such literature.

Beyond advancing her thesis about Straparola's adaptation of romances into restoration fairy tales, Bottigheimer proposes that he invented the plot of "rise tales," which she defines according to the formula of poverty-magic-marriage-money (2002:14). This category corresponds to what is often taken to be fairy tale today. The main basis for Bottigheimer's argument lies in a compact ten pages (2002:18-27) in which she closely paraphrases Straparola's early rise tales (to use the term that she proposes). Bottigheimer maintains that these rise tales were invented by Straparola in response to circumstances particular to his life in sixteenth-century Venice. A key question for anyone evaluating her book is whether or not Straparola invented rise fairy tales, which embody a narrative sequence that became a favored reflex of fairy tale in the nineteenth and twentieth centuries.

\section{Rise Tales in the Context of Folktale and Fairy-Tale Studies}

The pattern that Bottigheimer isolates requires a particular level of economic development, since the final monetary element in the sequence poverty-magic-marriagemoney would not have been as important in the early Middle Ages as it was in the later Middle Ages or in the early modern period (Little 1978). If it were presented instead in nonmonetary terms as adversity-magic-marriage-prosperity, the pattern would be likelier to be found in more cultural contexts distributed more broadly across time.

Do rise tales differ fundamentally from restoration tales, as Bottigheimer posits? It could be countered that this presentation of the tales focuses upon the plot (the word Bottigheimer uses, whereas others might prefer narrative: see Hawthorn 2000:336-8) as much as upon the setting. Or, to look at the matter differently, it could be argued that her analysis deals as much with the accidents of the stories as it does with their essential qualities. In folktale and fairy-tale studies, the tools for analyzing the accidentals of the stories have been developed by successive generations of scholars, from Johannes Bolte 
and Jiří Polívka in their thousands of pages of notes on the fairy tales of the brothers Grimm (Bolte and Polívka 1913-1932), through the tale-type index made famous by Antti Aarne and Stith Thompson (1961) and expanded recently by Hans-Jörg Uther (2004), to collective enterprises still underway that are bringing scholarship into the twenty-first century (such as the magisterial Enzyklopädie des Märchens, the initial volume of which was published under the editorship of Kurt Ranke in 1977). A portion of this effort has been directed to collecting and inventorying tales, subsuming them according to specific tale types, and isolating motifs within them. As far as the essential, formal qualities of folktales and fairy tales are concerned, the name that holds preeminence is that of Vladimir Propp, whose Morphology of the Folktale (1968) unfolded a system for analyzing Russian wonder tales with reference to thirty-one episodes or functions. Bottigheimer offers a means of sweeping aside the clutter that has accumulated from past scholarship on both the accidents and the essential qualities of tales: in place of the multiplicity that the Finnish method produced or the thirty-one functions of Propp's formalism, she locates the origins of an entire genre in the singleness of one author and one collection of tales.

While probing basic issues, we should ask whether Bottigheimer's stark positions help us to a sharper discernment of the fairy-tale genre. Sometimes in scholarship a new and simple definition or approach clears the tangled undergrowth of accumulated erudition to allow the emergence of truths that have been latent but unrecognized all along. The adage about not seeing the forest for the trees can hold all too true, perhaps especially in those realms of study where data collection and data analysis are sometimes regarded as competing rather than complementary processes. In such cases it may be restorative to chop back old assumptions. But in other instances we have to be on guard against oversimplification.

In the matter of forests and trees, a balance seems advisable. For all the necessity to find patterns and not to become lost in particulars, there is at the same time an equal and not necessarily opposite need to pay attention to as many particulars as possible. This need for complexity does not have to entail indiscriminate rejection of all refinements and all categories. As in so many other cases where a stark duality can be posed, the middle ground has much to offer. A tree outside a forest can be sad and lonely, even misunderstood. A forest without trees is a contradiction in terms.

\section{Definitions of Fairy Tale}

Bottigheimer's volume has a strong and what may seem to folklorists a strange or even perverse agenda. Its title promotes the salience of fairy tale within itself, by first presenting Straparola as "fairy godfather" and then connecting him with "the fairytale tradition." I have no doubt that Straparola's work is important and that it would be invaluable to have annotations to it on the order of what Bolte and Polívka provided for the Grimms' fairy tales-an as-yet imaginary reference work that could be entitled Anmerkungen zu den Piacevoli Notti (Notes on the Pleasant nights). One attraction of such annotations would be that they could be concerned equally with sources and influences. In other words, I see Straparola's tales as falling somewhere in the middle, chronologically and generically, of the available data for the genre that 
has come to be known in English, enduringly and misleadingly, as fairy tale. Straparola's tales had predecessors as well as successors.

Genre (along with motif and tale type) is a key category in folktale and fairy-tale research: it is only logical that the definitive exposition of the methods and procedures for classifying folk literature should be entitled Motif, Type, and Genre: A Manual for Compilation of Indices and a Bibliography of Indices and Indexing (Jason 2000). Genre is often defined as a tool for the taxonomy of literature that has been devised by literary scholars and that is distinct from the native categories that were employed in earlier times or that are applied outside the confines of literary scholarship. Great tensions can exist between the literary and the native categories, and fairy tale is a case in point. On the one hand, scholars may maintain the well-known native terminology, although they will then have to endure the inevitable confusion that arises as a result of the unscholarly assumptions that come with the old words. On the other hand, they may coin altogether new terms or at least specify the native terms so as to clarify their meanings and applications. Folklorists have striven valiantly to accomplish the necessary disentanglement, with one major contribution being a collective volume titled Folklore Genres, edited by Dan Ben-Amos, that was published in 1976. Genre thus stands out as a category important in folkloristics. Nevertheless, its importance has not translated into major advances or consensus about pivotal terms such as "fairy tale." Tellingly, the most recent definitions of fairy tale in a standard textbook, Folkloristics: An Introduction (Georges and Jones 1995), date to 1965, and the terms "fairy tale" and "Märchen" are used interchangeably in the discussion of the genre there. In contrast, the term "fairy tale" does not even appear in another introduction to the field, The Dynamics of Folklore (Toelken 1996).

The supplementing of fairy tale or its equivalent in other languages (such as Märchen in German) with additional modifiers is an old practice: to cite the foundational example, the brothers Grimm gave prominence to the practice by entitling their collection Kinder- und Hausmärchen (Children's and household tales) ([1812-5] 1980). Bottigheimer's innovation is to have adjusted fairy tale by first prefixing it with a monosyllable and then contending that the resultant term - "rise" fairy tale (2002:4) or "rise tale" (2002:6-152) - describes a phenomenon that began at a particular moment in time and that represents the essential core of fairy tale as it has since come to be conceived.

Bottigheimer's contentions about the rise tale contradict the assumption that genres of - to use an ineluctable oxymoron-oral literature have a fundamental stability over the millennia for which written documentation is available (Jason 2000:35). If her contentions hold true, then fairy tale would not belong to the domain of oral literature, and countless volumes of folklore scholarship would turn out to rest on illusory presuppositions.

\section{The Ancient and Medieval Background of Fairy Tales}

The set of arguments that Bottigheimer articulates runs counter to the impressions I have garnered from years (however far from sufficient) of trying to comprehend the interplay of what I regard as folktales and fairy tales with texts, in classical antiquity 
and especially in the medieval West. Others will have to undertake the task of testing, whether by applying the so-called historic-geographic method or by engaging in reception studies, the assumption that a little more than a dozen wonder tales included in Straparola's Le piacevoli notti could have given rise to all other wonder tales in existence today throughout the world. My own contribution will be to raise a few strong concerns about the validity of the assertion that Straparola was indebted solely to written materials, some of which went back to the Middle Ages, for restoration tales, and to nothing more than his own fantasy for rise tales. I have encountered some texts from antiquity and even more from the Middle Ages that I believe are based essentially upon, or have embedded in them, folktales. Furthermore, I have become convinced that some of them can be considered fairy tales, as that term is understood today by many general readers and by many scholars. The brothers Grimm, who among other things were students of the Middle Ages, held that a distinctively German culture constituted in the medieval period had persisted down to their day among members of the most humble and least educated social classes (Ziolkowski 2007:166-9). It is thus not accidental that fairy tales acquired the medieval or medievalizing trappings of princesses, knights, castles, and so forth. But were the brothers Grimm right in their reading of the evidence and in their subsequent construction of the tales they wrote, which were neither fish nor fowl, neither oral folktales nor literary fairy tales? Did folktales and fairy tales exist or even originate in the Middle Ages?

Incomplete as my recent book may be in its coverage of possible materials, Fairy Tales from Before Fairy Tales: The Medieval Latin Past of Wonderful Lies (2007) makes what has been in the past few decades the fullest attempt to muster evidence that folktales in general and fairy tales in particular began to wend their way into writing, despite clerical resistance to them, in the central Middle Ages. One hundred twentyfive of its five hundred pages are given over to translations of the Medieval Latin texts that it analyzes, together with the English of related narratives from earlier and later times. The five appendixes offer readers the opportunity to arrive at their own judgments by comparing and evaluating independently the relationships between the Latin texts from the Middle Ages and the sources, derivatives, and analogues. In three of the major groupings within this sourcebook, the Medieval Latin texts are related to tales from the brothers Grimm and from Hans Christian Andersen. In two of these cases the brothers Grimm can be shown incontrovertibly to have relied directly upon Medieval Latin poems as sources, and in two cases texts from Straparola are also included because of their strong resemblances to the tales preserved in the Medieval Latin poems.

\section{Straparola in Comparison with Versus de Unibove and Asinarius}

Let us examine specifics. Perhaps the resemblance of Straparola's tale of "Pre Scarpafico" (night 1, story 3) to the eleventh-century Versus de Unibove (Poem about One$\mathrm{Ox}$ ) can be rejected with the argument that the medieval tale recasts in Latin verse a folktale rather than a fairy tale. Furthermore, "Pre Scarpafico" is clearly not bound by a direct, text-to-text relationship to Versus de Unibove, even though it does contain almost all of the central motifs that appear in Storia di Campriano contadino (The 
story of the peasant Campriano), which was in print by 1518 at the latest (and was printed three more times before Straparola wrote his version). All of these stories belong to the same branch of the great family tree of short narratives wherein are also subsumed the brother Grimms' "Das Bürle" (Little farmer) and Hans Christian Andersen's "Lille Claus og store Claus" (Little Claus and Great Claus).

But even if we dismiss "Pre Scarpafico," what do we do with the likenesses of "Il re porco" (The prince pig; night 2, story 1) to Asinarius (The donkey tale), another Medieval Latin poem from around the year 1200? "Il re porco" is the first tale that Bottigheimer analyzes in detail (2002:18-20), and it is the first of the proposed "rise tales" in Straparola's work. In the most recent iteration of the standard tale-type index, Straparola's tale has been classed as ATU 441 ("Hans My Hedgehog"), and we are indeed informed there that "the oldest complete literary text is Straparola" (Uther 2004, vol. 1:263). (The abbreviation ATU refers to Uther's Types of International Folktales, which supplants Aarne and Thompson's 1961 Types of the Folktale, which first appeared in 1927 and was itself based on a German work that Aarne alone published in 1910. The collaborative work of Aarne and Thompson was a fulcrum in folkloristics, in many types of philological inquiry, and in thematic research in literary history, for much of the twentieth century. It may be understandable and justifiable that ATU should be less known and less used by folklorists in the twenty-first century, but such a transition, if it is taking place, should not pass unremarked and undiscussed.) The index summarizes ATU 441 as follows:

A previously-childless couple (because of a hasty wish or a curse) has a son who is a hedgehog. He becomes a swineherd in the forest, where the pigs thrive under his care. He gives directions to three (two) kings (merchant, count, king, one king three times, etc.) who have lost their way, and is promised one of their three daughters as his wife.

Riding on a rooster, he goes to claim his bride three times. Two of the princesses refuse him and he scratches them, but the third agrees to marry him. On the wedding night (on the way to the church, after they have lived together), the animal's skin is destroyed (the princess kisses the hedgehog, whips him, cuts off his head, etc.). The hedgehog is disenchanted and turns into a handsome young man. (The two other princesses kill themselves from jealousy and anger.) (Uther 2004, vol. 1:263)

The best-known version of this tale is "Hans mein Igel" (Hans my hedgehog), by the brothers Grimm in Kinder-und Hausmärchen ([1812-5] 1980, tale number 108; trans. in Ziolkowski 2007:361-5).

The index's discussion of ATU 441 also points us to two other tale types. One is ATU 425C ("Beauty and the Beast"), closely related to ATU 425B ("Son of the Witch," known conventionally as "Cupid and Psyche"). (For an exhaustive but frustratingly unindexed analysis-according to the geographic-historical method-of evidence relating to this tale, see Swahn 1955.) The other tale cross-referenced at ATU 441 is ATU 433B ("King Lindorm"). Furthermore, ATU 425A (“The Animal as Bridegroom”), although not cross-referenced at ATU 441, itself contains cross-references not only to ATU 441 but also to ATU 430 ("The Donkey"), of which the first attestation in the West is given as the Medieval Latin poem Asinarius (Uther 2004, vol. 1:256-7). This 
tale eventually earned a place in an adaptation by the brothers Grimm, included in Kinder- und Hausmärchen under the title of "Das Eselein" (The donkey) ([1812-5] 1980, tale number 144; trans. in Ziolkowski 2007:353-5). The Grimms' adaptation was based directly on the Medieval Latin poem. It is recapitulated in Uther's index in the following three paragraphs:

After a royal couple has long wished for children, the queen finally gives birth to a donkey. Raised as a human, he learns courtly customs and how to sing and play the lyre (harp, etc.)

On the day when he first sees a reflection of his face, he runs away accompanied by a servant. In a foreign country he entertains the king's court with his musical talents. He meets the king's daughter and is charmed by her beauty.

When the donkey wants to return home, the king tries to prevent him by offering him his daughter in marriage. On the wedding night the donkey takes off his skin and turns into a handsome prince. A servant who observes this tells the king, who burns up the skin on the following night. The prince, unable to become a donkey again, wants to flee, but the king stops him and gives him part of his kingdom. (2004, vol. 1:256-7)

What ties together these tales? Albeit narrated from the viewpoint of a female character, Straparola's "Il re porco" relates a tale substantially the same as that recounted by the male narrator of Asinarius: an ugly animal who weds a princess turns out to be a handsome youth and becomes king when the animal skin in which he has been enveloped is burnt.

\section{Three Grimm Tales and John of Alta Silva}

Nor is it Straparola alone whose tales betray resemblances with medieval texts. The first Grimm tales upon which Bottigheimer touches (2002:8) are "Die zwölf Brüder" (The twelve brothers), "Die sieben Raben" (The seven ravens), and "Die sechs Schwäne" (The six swans), all three in the Kinder- und Hausmärchen ([1812-5] 1980, tale numbers 9, 25, and 49). These tales are versions of ATU 451 ("The Maiden Who Seeks Her Brothers"), the first recorded instance of which is in the twelfth-century Dolopathos sive De rege et septem sapientibus (Dolopathos, or The king and the seven wise men), written by a Cistercian monk, John of Alta Silva (or John of Hauteseille, as the monastery is known in French) (John 1981). Loosely related to the Arabian Nights, John's frame tale in Latin prose features wise men who tell tales each day so as to save the protagonist from death, in this case at the instigation of a wicked stepmother. John's version of ATU 451 is particularly relevant because, like the Asinarius poem, it contains hints of having had Eastern origins and of having drawn on oral tradition (Ziolkowski 1998:25-36). Bottigheimer sees Eastern material as having contributed substantially to fairy tale and views Italy as having played a pivotal role in the mediation of this development, but she dates the exchanges to the precise time of Straparola instead of establishing a continuum with documents such as John's text that were composed many centuries earlier. 


\section{Bottigheimer's Attack on Oral Tradition}

From the perspective of folkloristics and even of fairy-tale scholarship in general, Bottigheimer's Fairy Godfather: Straparola, Venice, and the Fairy Tale Tradition launches an assault on both "fairy tale" and "tradition." First Bottigheimer announces that she will eschew the term "fairy tale" in favor of the less loaded words "story," "tale," and "plot." Then she describes two types of tales that replace the rejected "fairy tale." The final words of the subtitle also put on the marquee the term "tradition," which has a specific usage, not restricted to folklorists, that often renders redundant the adjective "oral." In linguistic terms, "tradition" as an unmarked word in folkloristics-and even as it has reached general usage outside the discipline-implies orality. The word must be marked by modifiers such as "literary," "religious," or "musical" to specify other circumstances. To cite one standard dictionary, tradition is "the passing down of elements of a culture from generation to generation, especially by oral communication" (Morris 1969:1360). Or to quote another, tradition is "the handing down of information, beliefs, and customs by word of mouth or by example from one generation to another without written instruction" (Merriam-Webster's 2006:1325).

If dictionaries of the English language are deemed not sufficiently professional to establish or even to characterize usage within folkloristics, then the corresponding entries in handbooks of folklore should carry more weight. The entry on tradition in Folklore: An Encyclopedia of Beliefs, Customs, Tales, Music, and Art specifies in its second sentence that "in general, folklorists have maintained a particular interest in those [traditions] that are orally transmitted" (Green 1997, vol. 2:799). The entry for the term in the Encyclopedia of Folklore and Literature sums up that, "[b]y the late 1960s, tradition was generally defined as the passage of oral, gestural, material, and customary lore from one person, place, and generation to another by word of mouth or by imitation" (Brown and Rosenberg1998:658). Folklorists may no longer see tradition as being necessarily oral, and they may pay increasing attention to the interplay of tradition and innovation in all forms of cultural expression, but at the same time oral tradition remains central within the concerns of folklorists (see Glassie 2003). In this regard, Bottigheimer has a revolutionary mission that undercuts her titular traditionalism. Although her biases show clearly early in the book, only toward the end do we find the phrase "oral tradition" enclosed in scare quotes (2002:130).

Tradition of the oral sort turns out to be a phenomenon Bottigheimer presents as being hopelessly elusive before the introduction of phonographic recording in the 1870s. A slogan, probably around fifty years old and quaint in ways that would have disconcerted its original exponents, advocates that we "Question Authority," but Bottigheimer follows a simpler (and possibly simplistic) principle of "Question Orality." In her view, not only is it pointless to conjecture about oral traditional literature before unambiguous records of it survive, but in addition it is wrongheaded to suppose that oral tale-telling ever made a creative contribution to the fairy-tale tradition as she defines it in the subtitle to her book.

To look for the creators of what has passed under the name of fairy tales, Bottigheimer maintains that we must seek out the earliest written testimonies that conform 
to our definition of the genre. This standard would seem to be inconsistent with the basic mission of the third chapter of her book, which adumbrates "A Possible Biography for Zoan Francesco Straparola da Caravaggio." The chapter opens with the admission that, "The life of the man known to the world since 1551 as Giovan Francesco Straparola is a nearly blank sheet" (2002:45), and yet Bottigheimer goes on to fill not just one sheet but a few quires with a reconstruction based on inferences (45-81). She does not clarify why she allows hypothesis on the basis of contextual information when constructing a biography but not when piecing together the history of a tale.

\section{Printed Texts and Lost Literature}

Bottigheimer's outlook reflects in large part the field of expertise to which she has committed herself, since by and large she directs her attention to print sources from the sixteenth century and later. After demolishing (without even deigning to name it) the historic-geographic method for the analysis of oral traditional literature, she proceeds to unfold a system that assumes exactly the same method-except using only written texts as the bases for inference. According to her reasoning, Italy in general and Venice in particular held importance because of their favorable positions in trade routes that ran both north-south and east-west. These lines of transmission allowed for the entire peninsula and especially the lagoon city to benefit from the influence of other cultures and in turn to constitute a source of inspiration for them-but through the vehicle of printed texts, not through some notional orality. The devotion to printed texts from the early modern period forward marks Bottigheimer apart in her preoccupations and presuppositions from both the relatively few literary scholars who contend with earlier literature and the folklorists who immerse themselves in oral literature.

Classicists and medievalists who occupy themselves with literature may have an understandable bias toward texts, but at the same time, more than literary historians who specialize in the modern era, they have to be routinely alive to what has been lost. In a delicious paradox, we have entire printed books to enumerate compositions that are known to have existed in antiquity or the Middle Ages but that have since vanished (for example, see Bardon 1956; Deyermond 1995-; Wilson 1970). Furthermore, while the reconstructive enterprise of the sundry philologies (classical philology, romance philology, Germanic philology, and so forth) in which classicists and medievalists frequently engage proceeds customarily on the basis of textual criticism that has little or no connection with the principles of oral traditional composition or transmission, it also requires constant alertness to what may lurk behind the printed texts on which we rely today. Although Bottigheimer has in common with scholars of earlier literature an emphasis on written texts, she differs from them in rejecting the urgency of seeking out behind extant written versions earlier ones that may not have been successfully transmitted to the present day.

Folklorists, meanwhile, pay heed to oral versions of tales. In the past they sometimes preferred oral versions and devalued written evidence as being contaminated or derivative. Today they tend in examining oral versions to attend to differences between oral presentations and those in script, print, and other media. Bottigheimer may reject oral versions and even the notion of oral tradition - not an ATU or Motif-Index 
number appears between the covers of her book-but she shares with folklorists a skepticism about drawing inferences from printed testimonies. In her system, such testimonies cannot be used to help us triangulate as we seek to understand missing forms of either written or oral evidence.

Bottigheimer will have none of reconstruction that rests upon suppositions about conjectured oral evidence. Instead, she adheres to a sort of logical positivism and wishes to have the concreteness of printed pages. Or maybe her position should be termed empirical, in that she demands written evidence and privileges it over the reconstruction that is necessary for conjectures about what forms oral folk narratives would or could have taken. Direct written records of oral performances and especially of orally performed narratives (other than those of preachers) are exceedingly rare before the late Middle Ages. All that we have are the texts. True enough. But the texts give evidence of orality, not in a simple dynamic of literary source and its influence on orality (as Bottigheimer would have it), or oral influence that dominates the literary source (as extreme versions of folkloristics would contend). In fact, the relationship between textuality and orality-although not always couched in those two particular terms-has been scrutinized repeatedly over the past half century. One landmark came in 1960 with the publication of The Singer of Tales by Albert B. Lord, although this book was preoccupied with oral traditional poetry specifically and not with oral traditional narrative in general. The same qualification holds true for Oral Poetry: an Introduction by Paul Zumthor, originally printed in French in 1983 and in English in 1990. Despite these advances, the reality has yet to be accepted that from the Middle Ages on-and probably earlier-oral tradition has engaged in a constant, fruitful exchange with narratives preserved in manuscript, print, or both, as Rudolf Schenda has maintained (1993:222).

To extend the seeming dendromania that has pervaded this article, it is worth exploring a riddle that has emerged in discussions of Bottigheimer's thesis. Taking as a point of departure the old puzzler, "If a tree falls in a forest with no one to hear it, then does it make a sound?", Bottigheimer responds:

In the field of folk narrative a parallel statement of this philosophical conundrum would be: Is a tale heard when it is told in the absence of a listener? Here common sense tells us that only its teller hears the tale, which is, of course, irrelevant for questions of dissemination. Thus, in my opinion, the proposition that the absence of evidence is evidence for absence continues to stand. (2007:19)

The logical flaw in this response is that the parallel in folk narrative would be: Is a tale heard when it is told in the absence of a writer? Absence of evidence does not indicate the nonexistence of a phenomenon, any more than the absence of a person from a room of observers indicates that the individual in question has ceased to be or has never existed.

Bottigheimer is keen to espouse a clear and powerful theory that will elucidate the dynamics of the texts with which she concerns herself. To draw an analogy with science, she makes past scholars look as if they stopped at the molecular level whereas she has progressed to the more profound comprehension that comes from particle 
physics. Aarne, Thompson, and Uther would appear to be organic and inorganic chemists, working with hundreds of narrative strands. For instance, they categorize as fairy tales the wonder tales that are designated as ATU 300-749. Propp took a different approach, finding that all of the 450 tales in the Aarne-Thompson system could be subsumed into thirty-one functions. In effect, Propp produced a periodic table to enumerate all of the elements that combined to form the tales catalogued by Aarne and Thompson. But these feats, by Aarne-Thompson and Propp, pale in comparison with those of Bottigheimer, who takes things to the atomic level by positing that all of what deserves the name of fairy tale clings to just two patterns. Exactly as a particle physicist would not need to cite the findings of chemists, so Bottigheimer can dispense with even dismissing the names of Aarne, Thompson, and Propp. They warrant no mention in Fairy Godfather: Straparola, Venice, and the Fairy Tale Tradition, since their missions differ fundamentally from hers.

In keeping with the scientific rigor that Bottigheimer professes, she even offers elementary line diagrams to illustrate her two types of tales. First come restoration tales, in which hero(ines) begin in wealth, are expelled from it, and are finally restored to it. She charts such tales (2002:11) as conforming to the pattern V. Next she describes rise tales, which she sees as being similar to rags-to-riches tales in tracing an ascent from poverty to wealth, which can be rendered graphically (2002:14) as /. In rags-toriches tales, upward mobility comes through chance or wit, whereas in rise tales magic constitutes the force that enables marriage to royalty, resulting in wealth. According to Bottigheimer, Straparola's tale collection stands out for the fact that all of the hitherto-unattested tales it contains are ones in which the main narrative culminates in a wedding.

Rejection of both the oral and the popular is an intrinsic feature of classicism, perhaps particularly of Latin classicism. Much of the Latin literary tradition was what C. S. Lewis termed "secondary" (1961:40), meaning that it was highly literate and had as its foundation not the primary and oral epics of Homer but the exceptionally literary epic of Vergil. But none of this is to say that Greco-Roman antiquity somehow lacked folktales in general and the equivalents of what we call fairy tales in particular. Alongside such venerable efforts as Rhys Carpenter's Folk Tale, Fiction, and Saga in the Homeric Epics (1946) stand (to name only a couple of examples from our own century) broader efforts such as Graham Anderson's Fairytale in the Ancient World (2000) and William Hansen's Ariadne's Thread: A Guide to International Tales Found in Classical Literature (2002). We could view these books skeptically as being misguided or at best quixotic, particularly the last two, in endeavoring to establish ties between texts from the classical period and tales represented in international folklore, even among children's fairy tales today; however, we would have to surmount a few hurdles in dismissing all of the evidence that such research has adduced.

\section{Apuleius's "Cupid and Psyche"}

The pattern that Bottigheimer describes as a rise tale calls to mind more than a little the centerpiece among the various inset tales that are enclosed within the main framework of Apuleius's Golden Ass, a second-century work that is the only complete extant 
ancient Latin novel. (The frame tale, about a man transformed into an ass, itself has a complex relationship to oral tradition; for the fullest study, see Scobie 1983). The tale in question happens to be heard by the narrator while he is literally asinine, since he has been turned into a donkey (for a fuller analysis, see Ziolkowski 2002:90-113). A young Roman male would not normally have been privy to many of the stories that he overhears, and perhaps especially not to this one, which is told by an old womanfactotum for a band of robbers-to a young woman who has been kidnapped from her own wedding feast. Not only is the tale told to a young woman on the day of her nuptials, but in addition the tale itself culminates in a marriage.

The tale is conventionally designated as the tale of "Cupid and Psyche" (ATU 425B "Son of the Witch"); it was briefly mentioned above in relation to Straparola's tale "Il re porco." It relates how Psyche, the youngest of three daughters, was so beautiful that people neglected Venus out of admiration for her. Jealous, Venus sends Cupid to make Psyche fall in love with some unsuitable creature, but instead Cupid falls in love with Psyche and places her in a palace. Cupid appears in the palace only by night, in the dark, and forbids Psyche to attempt to look at him. Her envious sisters, saying that her lover is a monster, persuade Psyche to kill him. One night, after taking a lamp so that she may see and slay the beast, she spills a drop of hot oil on him. Angry, Cupid leaves. Thereafter, Psyche wanders the earth in search of him and confronts a series of seemingly impossible tasks that she accomplishes only with magic help. In spite of Psyche's flubbing of her final assignment, she and Cupid marry and presumably live happily ever after.

The old woman who recounts this tale describes it as belonging to the category of "pretty fablings and old wives' tales" (narrationibus lepidis anilibusque fabulis) (Apuleius, Metamorphoses 4.27). She begins the tale as follows:

Erant in quadam ciuitate rex et regina. His tres numero filias forma conspicuas habuere, sed maiores quidem natu, quamuis gratissima specie, idonee tamen celebrari posse laudibus humanis credebantur, at uero puellae iunioris tam praecipua tam praeclara pulchritudo nec exprimi ac ne sufficienter quidem laudari sermonis humani penuria poterat. (4.28)

[Once upon a time there lived in a certain city a king and queen, and they had three daughters remarkably beautiful. But though the two elder girls were as comely as you could wish, yet it didn't strike you dumb with despair to have a look at them-while as for the youngest girl, all man's praising words were too poor to touch (let alone becomingly adorn) a beauty so glorious, so victorious.] (Lindsay 1960:104-5)

This opening leaves no question about the world that we have entered: the emphatic vagueness of time and place, the cast of characters with three sisters, the youngest of whom is a beauty, and soon enough, as the passage continues with a long description of the wrath of Venus at having such a competitor (4.28-31), the indefatigably spiteful older woman who stands in Psyche's way-surely we have entered a never-never land populated by the likes of Cinderella.

The contrast could not be stronger to the world outside the tale, in which the tale 
is told orally by the basest of base creatures, a raving, drunken old woman who serves criminal outcasts. The narrator comments:

Sic captiuae puellae delira et temulenta illa narrabat anicula; sed astans ego non procul dolebam mehercules quod pugillares et stilum non habebam qui tam bellam fabellam praenotarem. (6.25)

[Such was the tale told by the crazy drunken old woman to the captive young girl. I stood not far off, grieving by Hercules! that I had no tablet and pen to note down so pretty a nonsense.] (Lindsay 1960:142)

The words here are technical terms about the teller, tale, and telling context. They give a hint of the tale types associated with old women-one of the most difficult groups of taletellers in ancient Greece and Rome for current scholars to access because of these women's humble social standing and distance from literacy (the fullest study of this material is Ziolkowski 2002). But fortunately, the concepts "difficult" and "impossible" differ, and we should no more avoid coming to terms with the tales associated with old women than with the stories linked with slaves and freedmen. The tales of old women elicited ongoing contempt from literary commentators, starting in Plato's Theaetetus (176b), Gorgias (527a), and Republic (1:350e). The hostility to their traditions stands to reason, since in many respects the old women represented an opposite to the approved culture of educated men just as much as did the barbarians outside Greek and Roman culture. Their traditions encompassed not merely fright tales of bogeymen and cautionary tales, but also a gamut of other narratives, such as Aesopic fables, hero tales, tall tales of the "Land of Cockaigne" type, wonder tales, romantic tales, and so forth. (Among the many passages that could be cited, the most important mentions of such tales are probably in Philostratus: Life of Apollonius 5.14 and Imagines 1.15.)

The tales of old women had to be controlled, which usually meant suppressing them before they came to be written. But they existed, as the repeated denunciations indicate. Does all of this presuppose that Apuleius himself obtained the tale of Cupid and Psyche by collecting it from an old woman? Certainly not. But it does imply that already in his day tales like it were thought to belong within the domain of orality and that this particular one had embedded in it wisdom or life experience that would be particularly likely to be passed by an older woman to a younger one at the time of her nuptials.

\section{Medieval Literary Terms for the Sources and Transmission of Folktales}

Many other authors in both antiquity and the medieval period gave credit, either explicitly or implicitly, to the sorts of informants from whom they derived their stories or from whom they believed that such stories tended to be derived. The fourth volume of Bolte and Polívka's notes on the Grimms' fairy tales assembles an indispensable anthology of passages containing such statements (1913-32, vol. 4:41-94). But the list could (and should) be expanded considerably. Here, I will cite only the evidence from four of the tales with which I wrestled most closely in my book (Ziolkowski 2007).

Letaldus of Micy, in his tenth-century Latin poem about an episode, reminiscent of 
both Jonah and Pinocchio, in which a fisherman is swallowed by a whale, claimed to have learned the story by word of mouth from an old man: "Moribus hoc senior venerabilis et gravis aevo / rettulit, os cuius rutilum splendescit ut aurum" (An elder, commanding respect by his behavior and weighted down by age, whose words are radiant like copper-tinged gold, reported this event) (Bertini 1995, lines 7-8; trans. and discussed in Ziolkowski 2007:69). Likewise, in the very first line of an early eleventh-century poem, Fecunda ratis (The richly laden ship; written between 1022 and 1024), which may record a version of "Little Red Riding Hood," the schoolmaster Egbert of Liège states that country folk already know this tale: "Quod refero, mecum pagenses dicere norunt" (What I have to relate, country folk can tell along with me) (lines 1-2; quoted and trans. in Ziolkowski 2007:103).

In seeming contrast to these mentions of folk origins, the eleventh-century Latin poet of Versus de Unibove (mentioned above in relation to Straparola's tale of "Pre Scarpafico") does not claim that his tales of a peasant trickster originated among peasants, and in fact he refers to its delivery "at the table of a great prince":

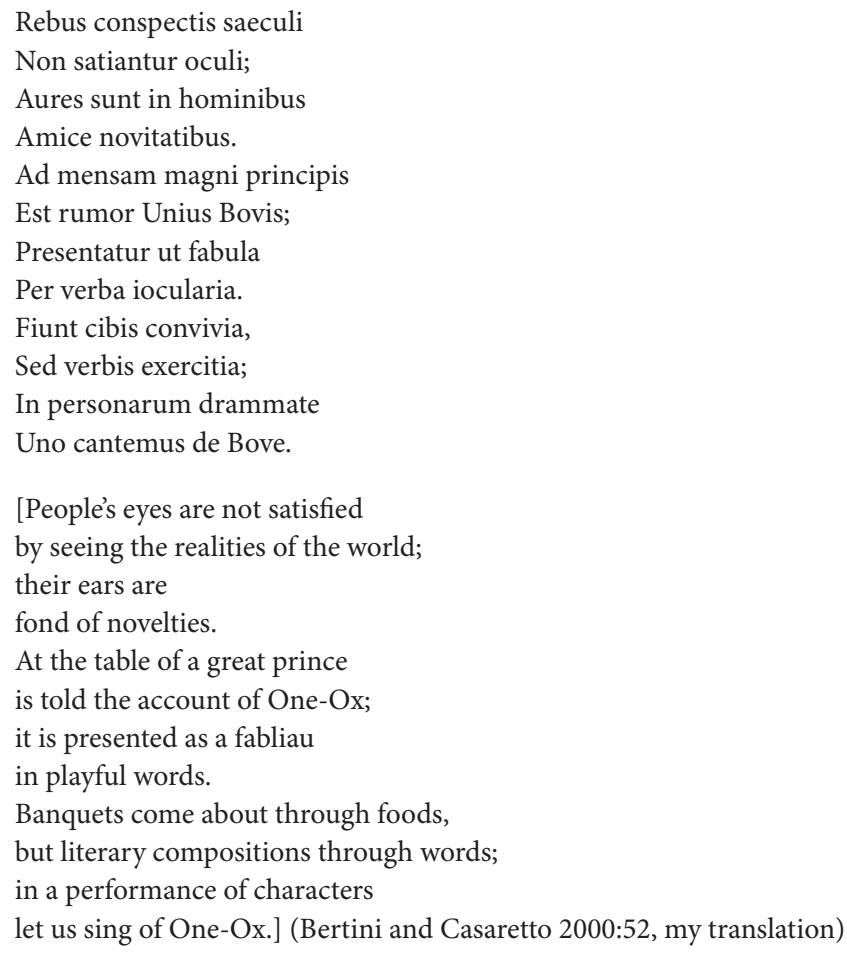

At the same time, the poet claims that his literary composition about a wily peasant is a song hitherto unknown to his audience. In designating his tales, he uses terms (Latin nouitates and fabula) that anticipate-by centuries - the newness emphasized in the Italian word novella and the element of talk at the root of the Old French fabliau (see Ziolkowski 2007:16-17, 129). In addition, the phrase uerba iocularia (playful words) incorporates an adjective (iocularis, $-e$ ) that may call to mind the oral performers designated in French as jongleurs. Literary-critical terms in premodern texts must be approached with a delicacy commensurate with the fascination they awaken. Here, 
a particularly intriguing parallel is offered by Straparola, who (as Bottigheimer maintains) refers to his narratives "not as novelle [the plural of novella] ... but as favole [the plural of an Italian derivative of fabula and also a cognate of fabliau], a less esteemed genre. His word choice provides a sure indication that he was conscious of the fact that his narrative composition diverged from traditional narratives" (Bottigheimer 2002:85). In one standard historical and etymological dictionary of Italian, the noun favola is defined as a "brief composition in which even inanimate objects appear among the interlocutors [= fable]; novella, contrived narration, something untrue [= fib]; semi-learned word from the scholastic tradition" (Battisti 1975, vol. 3:1609). What is the upshot? Favole here do not necessarily stand any lower in the literary hierarchy than do novelle; in fact, they may rate as being higher in prestige.

Finally, and perhaps most revealingly of the complex stature of folk narratives (including fairy tale) in Western culture, is the text of Asinarius, the Latin poem from around 1200 that was discussed above in the context of Straparola's "Il re porco." This poem is preserved in different versions that contain two starkly different choices for its opening couplet (for a further analysis, see Ziolkowski 2007:225):

Rex erat ignote quondam regionis et urbis

Sed nomen regis pagina nulla docet.

[Once upon a time there was a king of an unknown region and city,

and, what is more, no page tells the king's name.] (Langosch 1929:15; my translation)

or,

Rex erat ignote quondam regionis et urbis

Sed nomen regis fabula nulla docet

[Once upon a time there was a king of an unknown region and city,

and, what is more, no tale tells the king's name.] (Rizzardi 1983:194; my translation)

A better emblem for the medieval prototypes of folktales and fairy tales, shuttling between the literate and the oral, between the learned and the popular, between the high and the low, could hardly be imagined, since the first of these couplets favors the word pagina (page) and the second fabula (tale).

\section{The Movements of Tales Up and Down Social Hierarchies}

When surveyed from a great distance, the occasional frictions between philology and folkloristics can be seen to replay variations on a tension that has been present for millennia. Many of the different movements that can be subsumed under the heading of classicism and that have produced literature, particularly "high" literature, manifest a striking opposition to the social groups that may be most readily associated with folklore. Examples would be slaves and other oppressed social classes, such as women. Perhaps the most notorious would be old women, whose "old wives' tales" once incorporated not just pseudo-science but many other sorts of lore, including folktales.

How did these tales survive, if the literary tradition, and above all the Greco-Roman 
literary tradition, was so energetically and steadfastly opposed to folkloric materials? For one, classicism did not go unopposed. In late antiquity we have glanced at the stunning example of Apuleius, whose Golden Ass contains (as we have seen) the tale of Cupid and Psyche, narrated by none other than an old woman on a young woman's wedding day. In the Middle Ages we find, especially from the twelfth century on, texts that purvey tales from the East as well as from throughout Europe and that are sometimes presented explicitly as coming from the folk (or at least from professional entertainers who did not belong to the clergy). The process of identifying these tales is still underway, and the principal collections of tales have only scratched the surface (Berlioz, Bremond, and Velay-Vallantin 1989; Tegethoff 1925; Wesselski 1925). Not surprisingly, the work of interpreting them and fitting them into literary history has barely begun. Among later twentieth-century studies of medieval material, Maren ClausenStolzenburg's study of connections between medieval German literature and the German fairy-tale tradition paid close attention to Medieval Latin materials and might have presaged even greater achievements, had its author not died young (1995).

Coping with the implications of texts as heterogeneous and as enigmatic as these demands an eclecticism that differs strongly from the stances that Bottigheimer strikes. In her efforts to fell the sequoias of fairy-tale scholarship, she drives a number of wedges. One split Bottigheimer aims to achieve is between fairy tale (renamed and redefined by her as rise tale) and folktale. Another is between fairy tale and a rural setting among peasants, since she maintains that the genre originated not in the countryside among an indeterminate "folk" but instead in a city in the creative mind of an individual author.

The temptation to formulate dichotomies runs strong when phenomena such as orality and literacy come into play. For at least a couple of centuries, people, or at least scholars, have sought out absolutes when it comes to fairy tales. Those who have grappled with oral and written sources have tended to generalize and to privilege one over the other. This extremism is personally and professionally self-serving, since literary scholars even beyond Bottigheimer have tended to maintain that print prevails over oral, whereas folklorists have favored the oral over the written. Literary scholars and folklorists alike have wanted to be able to determine that this story had oral origins, that one written; this tale qualifies as folklore, that one as fakelore; and so forth. Many have been seduced by either/or models in which culture has always moved downward from the elite class (gesunkenes Kulturgut) or upward from the "folk" (gehobenes Kulturgut) (see Ziolkowski 2007:60).

In The Dialogue of Solomon and Marcolf-itself a text that unites the gesunkenes and the gehobenes - the leading character, a peasant named Marcolf, poses to King Solomon a riddle about an otherwise unidentified plural entity: "quanto plus ascendunt, tanto plus descendunt" (however much more they rise up, by that much more they sink down) (line 2.1.4; ed. and trans. Ziolkowski 2008:76-7). When Solomon asks, "Qui sunt ascendentes et descendentes?" (Who are those rising up and sinking down?), Marcolf replies, "Fabe in olla bulientes" (The beans boiling in the pot) (lines 2.1.8-9). Although I doubt that the author (or, likelier, authors) of the text intended to formulate a parable about literature, nonetheless the upward and downward movement of the beans in seething water speaks volumes, or tells many tales, about the constant interchanges 
between literacy and orality, between elite classes and subaltern classes, between insiders and outsiders, and between other categories too often presented as polar opposites. The truth is demanding and dynamic: we have to approach each tale in its own right, and we will often find a back-and-forth between written and oral or between oral and written. The Dialogue of Solomon and Marcolf is itself a case in point. The earliest unambiguous reference to a narrative clearly related to this so-called dialogue (but no longer extant, apparently in a Germanic vernacular, and not necessarily ever written) is from around $1000 \mathrm{CE}$. The Medieval Latin text as we have it is usually agreed to date to around 1200, but the earliest surviving manuscript is now put at 1410. What are we to make of the many testimonies - and of the many gaps in textual evidence?

\section{The Complexities of Fairy Tales}

Fairy tales have proven to be very refractory when it comes to neat bifurcations. They have been held conventionally to have originated in oral popular culture, but their "classic" expression has been first in printed books and later in commercial art forms, such as feature-length animated films, associated with mass culture. They have been assumed sometimes to be timeless, but many of them have been documented fully only over the past two centuries. The complications are probably inevitable, since no methods for recording oral traditions without the mediation of writing existed until after such oral traditions in Western Europe had been engaged in interplay with literature for hundreds and even thousands of years. Thus, fairy tales sit squarely where heavy traffic took place between the oral and the written-where, in the foundational expressions of what is often tagged the Parry-Lord theory or oral formulaic theory, a good body of medieval vernacular literature bids fair to be considered as "transitional texts" between orality and literacy. Albert B. Lord provided the basis for the discussion of "transitional" texts in his first major book (1960:124-38), and he revisited and refined this problematic classification often in his subsequent writings; his final statement appeared posthumously (1995:212-37).

Bottigheimer maintains that the first author to write an extant fairy tale, as she defines this term, initiated not only the tale but also the genre, and she contends that Straparola was this originator. These allegations give rise to a few objections. One is a matter of principle: that the first person to write a tale is not necessarily the first one to compose it. Another is a point of fact: that Straparola is not the first person to have written a fairy tale. But Bottigheimer's story does not end with her contention about the origins of fairy tales.

According to Bottigheimer, the thesis that Straparola invented the rise fairy tale has as its ineluctable corollary that such a narrative pattern did not exist before the mid1500s. From her perspective the only productive approaches to the affinities between the tales of Straparola and other tales that resemble them are ultimately by applying her contributions to genre theory in defining the "rise tale" and to literary history in tracing the subsequent print reception of Le piacevoli notti. Folklorists might prefer instead to define fairy tale in other ways and to take into account oral literature. And maybe a new class of eclectics, regardless of whether they define themselves as folklor- 
ists, literary historians, both, or neither, might wish to allow for the possibilities that we may never know whether a given story originated orally or in writing; that we must accept the impossibility of a universalizing theory that ties all tales of any given type exclusively to orality or literature, let alone to a single author; and that we have an obligation to approach each and every story with an open eye to possible orality lurking behind literature as well as to possible literature behind orality. Old dichotomies have broken down over the past few decades in the understanding of medieval literature: it has been recognized that Latin texts from the Middle Ages could have features indebted to orality, popular culture, and secular tastes, while the literary products of medieval vernaculars could be literate, learned, and Christian (Ziolkowski 1991, 2005). The models of sinking or rising have lost their plausibility as it has come to be understood that much more happened in the middle than was formerly granted.

There are definite attractions to a theory that would absolve us of the necessity to master old languages and to track what is found in cuneiform, papyri, palimpsests, and manuscripts, to single out only a few media in which discoveries lead regularly to revelations about the history of earlier cultures. Correspondingly, investigation of literary evidence would be easier if we could be freed of the obligation to piece together an interpretive framework by coming to terms with a discipline as methodologically complex and advanced as folkloristics. To those who would like to expound or to have expounded principles or theories that hold true without exception in all cases, life without absolutes can be disconcerting. At the same time, it can be much richer.

\section{References Cited}

Aarne, Antti, and Stith Thompson. 1961. The Types of the Folktale: A Classification and Bibliography. 2nd ed., FF Communications 184. Helsinki: Suomalainen Tiedeakatemia / Academia scientiarum fennica.

Anderson, Graham. 2000. Fairytale in the Ancient World. New York: Routledge.

Apuleius. 1940-1945. Metamorphoses, ed. D. S. Robertson, trans. Paul Vallette. 3 vols. Paris: Les Belles Lettres.

Bardon, Henry. 1956. La littérature latine inconnue. 2 vols. Paris: Librairie C. Klincksieck.

Battisti, Carlo, and Giovanni Alessio. 1975. Dizionario etimologico italiano. 5 vols. Florence: G. Barbèra.

Ben-Amos, Dan, ed. 1976. Folklore Genres. Publications of the American Folklore Society, Bibliographical and Special Series 26. Austin: University of Texas Press.

Bendix, Regina. 1997. In Search of Authenticity: The Formation of Folklore Studies. Madison: University of Wisconsin Press.

Berlioz, Jacques, Claude Bremond, and Catherine Velay-Vallantin, trans. 1989. Formes médiévales du conte merveilleux. Paris: Editions Stock.

Bertini, Ferruccio, ed. and trans. 1995. Letaldo di Micy, Within piscator. Biblioteca del Medioevo latino. Florence: Giunti.

Bertini, Ferruccio, and Francesco Mosetti Casaretto, eds. 2000. La Beffa di Unibos. Gli Orsatti: Testi dell'Altro Medioevo 9. Alessandria: Edizioni dell'Orso.

Birkhan, Helmut, Karin Lichtblau, and Christa Tuczay, eds. 2005-6. Motif-Index of German Secular Narratives from the Beginning to 1400.6 vols. Berlin: W. de Gruyter.

Bolte, Johannes, and Georg Polívka. 1913-32. Anmerkungen zu den Kinder- und Hausmärchen der Brüder Grimm. 5 vols. Leipzig: Dieterich'sche Verlagsbuchhandlung. 
Bordman, Gerald Martin. 1963. Motif-Index of the English Metrical Romances. FF Communications 190. Helsinki: Suomalainen Tiedeakatemia.

Bottigheimer, Ruth B. 2002. Fairy Godfather: Straparola, Venice, and the Fairy Tale Tradition. Philadelphia: University of Pennsylvania Press.

2003. The Ultimate Fairy Tale: Oral Transmission in a Literate World. In A Companion to the Fairy Tale, ed. Hilda Ellis Davidson and Anna Chaudhri, pp. 57-70. Cambridge: D. S. Brewer.

- 2007. Books, Folks, and Fairy Tales. ISNFR Newsletter (International Society of Folk Narrative Research), March, 18-9.

Brown, Mary Ellen, and Bruce A. Rosenberg, eds. 1998. Encyclopedia of Folklore and Literature. Santa Barbara, CA: ABC-CLIO.

Carpenter, Rhys. 1946. Folk Tale, Fiction, and Saga in the Homeric Epics. Berkeley: University of California Press.

Clausen-Stolzenburg, Maren. 1995. Märchen und die mittelalterliche Tradition. Beiträge zur neueren Literaturgeschichte, 3rd series, 138. Heidelberg: Universitätsverlag Carl Winter.

Cocchiara, Giuseppe. 1981. The History of Folklore in Europe, trans. John N. McDaniel. Philadelphia: Institute for the Study of Human Issues.

Deyermond, Alan. 1995-. La literatura perdida de la Edad Media castellana. Salamanca: Ediciones Universidad de Salamanca.

Georges, Robert A., and Michael Owen Jones. 1995. Folkloristics: An Introduction. Bloomington: Indiana University Press.

Glassie, Henry. 2003. Tradition. In Eight Words for the Study of Expressive Culture, ed. Burt Feintuch, pp. 176-97. Urbana: University of Illinois Press.

Green, Thomas A., ed. 1997. Folklore: An Encyclopedia of Beliefs, Customs, Tales, Music, and Art. 2 vols. Santa Barbara, CA: ABC-CLIO.

Grimm, Jacob, and Wilhelm Grimm. [1812-5] 1980. Kinder-und Hausmärchen, ed. Heinz Rölleke. 3 vols. Stuttgart: Philipp Reclam.

Hansen, William. 2002. Ariadne's Thread: A Guide to International Tales Found in Classical Literature. Ithaca, NY: Cornell University Press.

Hawthorn, Jeremy. 2000. A Glossary of Contemporary Literary Theory. 4th ed. London: Arnold.

Jason, Heda. 2000. Motif, Type and Genre: A Manual for Compilation of Indices and a Bibliography of Indices and Indexing. FF Communications 273. Helsinki: Suomalainen Tiedeakatemia.

John of Alta Silva. 1981. Dolopathos, or, The King and the Seven Wise Men, trans. Brady B. Gilleland. Medieval and Renaissance Texts and Studies 2. Binghamton, NY: Center for Medieval and Early Renaissance Studies.

Jolles, André. 1930. Einfache Formen: Legende/Sage/Mythe/Rätsel/Spruch/Kasus/Memorabile/Märchen/ Witz. Halle: Max Niemeyer.

Kiefer, Emma Emily. 1947. Albert Wesselski and Recent Folktale Theories. Indiana University Publications Folklore Series No. 3. Bloomington: Indiana University Press.

Langosch, Karl, ed. 1929. Asinarius und Rapularius. Sammlung mittellateinischer Texte 10. Heidelberg: Carl Winter.

Lewis, C. S. 1961. A Preface to Paradise Lost. New York: Oxford University Press.

Lindsay, Jack, trans. 1960. The Golden Ass. Bloomington: Indiana University Press.

Little, Lester K. 1978. Religious Poverty and the Profit Economy in Medieval Europe. Ithaca, NY: Cornell University Press.

Lord, Albert B. 1960. The Singer of Tales. Cambridge, MA: Harvard University Press.

- 1995. The Singer Resumes the Tale, ed. Mary Louise Lord. Ithaca, NY: Cornell University Press.

Merriam-Webster's Collegiate Dictionary. 2006. 11th ed. Springfield, MA: Merriam-Webster.

Morris, William, ed. 1969. American Heritage Dictionary. Boston: Houghton Mifflin.

Philostratus. 1912. Life of Apollonius, ed. and trans. F. C. Conybeare. Loeb Classical Library. 2 vols. London: William Heinemann.

1931. Imagines, ed. and trans. Arthur Fairbanks. Loeb Classical Library. London: William Heinemann. 
Plato. 1963. The Collected Dialogues of Plato, Including the Letters, ed. Edith Hamilton and Huntington Cairns. Bollingen Series 71. Princeton, NJ: Princeton University Press.

Propp, Vladimir. 1968. Morphology of the Folktale, trans. Laurence Scott, rev. Louis A. Wagner. 2nd ed. Publications of the American Folklore Society, Bibliographical and Special Series 9. Austin: University of Texas Press.

Ranke, Kurt, ed. 1977-. Enzyklopädie des Märchens: Handwörterbuch zur historischen und vergleichenden Erzählforschung. Berlin: de Gruyter.

Rizzardi, Simona, ed. 1983. Commedie latine dell XII e XIII secolo. Università di Genova, Facoltà di lettere, Pubblicazioni dell'Istituto di filologia classica e medievale 79. Genoa: Istituto di filologia classica e medievale.

Rosenberg, Bruce A. 1991. Folklore and Literature: Rival Siblings. Knoxville: University of Tennessee Press.

Schenda, Rudolf. 1993. Von Mund zu Ohr: Bausteine zu einer Kulturgeschichte volkstümlichen Erzählens in Europa. Göttingen: Vandenhoeck and Ruprecht.

Scobie, Alexander. 1983. Apuleius and Folklore: Toward a History of ML3045, AaTh567, 449A. Mistletoe Series 17. London: Folklore Society.

Straparola, Giovanni Francesco. [1551-3] 1898. The Facetious Nights of Straparola, ed. and trans. W. G. Waters. 4 vols. London: Society of Bibliophiles.

- [1551-3] 2000. Le piacevoli notti, ed. Donato Pirovano. Rome: Salerno Editrice.

Swahn, Jan Öjvind. 1955. The Tale of Cupid and Psyche (Aarne-Thompson 425 and 428). Lund: C. W. K. Gleerup.

Tegethoff, Ernst, trans. 1925. Märchen, Schwänke und Fabeln. Bücher des Mittelalters. Munich: F. Bruckmann.

Toelken, Barre. 1996. The Dynamics of Folklore. 2nd ed. Logan: Utah State University Press.

Uther, Hans-Jörg. 2004. The Types of International Folktales: A Classification and Bibliography. FF Communications 284-6. 3 vols. Helsinki: Suomalainen Tiedeakatemia / Academia scientiarum fennica.

Wesselski, Albert, trans. 1925. Märchen des Mittelalters. Berlin: H. Stubenrauch.

—. 1931. Versuch einer Theorie des Märchens. Prager Deutsche Studien 45. Reichenberg: F. Kraus.

Wilson, R. M. 1970. The Lost Literature of Medieval England. 2nd ed. London: Methuen.

Ziolkowski, Jan M. 1991. Cultural Diglossia and the Nature of Medieval Latin Literature. In The Ballad and Oral Literature, ed. Joseph Harris, Harvard English Studies 16, pp. 193-213. Cambridge, MA: Harvard University Press.

- 1998. Vergil as Shahrazad: How an Eastern Frame Tale was Authorized in the West. In Studies for Dante: Essays in Honor of Dante Della Terza, ed. Franco Fido, Rena A. Syska-Lamparska, and Pamela D. Stewart, pp. 25-36. Florence: Edizioni Cadmo.

- 2002. Old Wives' Tales: Classicism and Anticlassicism from Apuleius to Chaucer. Journal of Medieval Latin 12:90-113.

- 2005. Oral-Formulaic Tradition and the Composition of Latin Poetry from Antiquity through the Twelfth Century. In New Directions in Oral Theory, ed. Mark C. Amodio, Medieval and Renaissance Texts and Studies 287, pp. 125-48. Tempe: Arizona Center for Medieval and Renaissance Studies.

- 2007. Fairy Tales from Before Fairy Tales: The Medieval Latin Past of Wonderful Lies. Ann Arbor: University of Michigan Press.

- 2008. Solomon and Marcolf. Harvard Studies in Medieval Latin 1. Cambridge, MA: Department of the Classics, Harvard University.

Zumthor, Paul. 1983. Introduction à la poésie orale. Paris: Editions du Seuil.

- 1990. Oral Poetry: An Introduction, trans. Kathryn Murphy-Judy. Theory and History of Literature 70. Minneapolis: University of Minnesota Press.

Zumwalt, Rosemary Lévy. 1988. American Folklore Scholarship: A Dialogue of Dissent. Bloomington: Indiana University Press. 